\title{
SEDUM TENUIFOLIUM (SIBTH. \& SM.) STROBL SUBSP. IBERICUM NOV. SSP.*
}

\author{
H. 't HART \\ Instituut voor Systematische Plantkunde, Utrecht
}

\section{SUMMARY}

Within Sedum tenuifolium (Sibth. \& Sm.) Strobl two morphologically distinct forms can be recognised. These forms, characterised by the presence of long-stalked and short-stalked propagules, respectively, have different areas. The diploid of $S$. tenuifolium belongs to the shortstalked form, the hexaploid to the long-stalked form. The short-stalked form is newly described as ssp. ibericum, the name referring to its main area.

\section{INTRODUCTION}

Among the species belonging to the series Rupestria Berger of the genus Sedum, the well-defined Sedum tenuifolium (Sibth. \& Sm.) Strobl is certainly the most remarkable. Being well adapted to the mediterranean climate, it is the only species of this series with a definite resting stage in summer. Early in the beginning of the flowering period (June) all vegetative parts of the plant die, except for the last $0.5-2.5 \mathrm{~cm}$ at the tips of the non-flowering shoots. These parts swell to about twice their original thickness and then stop growing. Simultaneously the withered and dry leaves are all shed, except those attached to the thickened ends of the non-flowering shoots. Thus bare stalks are produced, which bear terminally propagules covered by a layer of imbricate dead leaves. In autumn these propagules form roots and also produce new leaves at their apices. During winter and spring $S$. tenuifolium is hard to distinguish from the other species of the series Rupestria.

The area of $S$. tenuifolium is by and large circum-mediterranean, extending from North Africa (Algeria, Morocco) and Southern Europe to Asia Minor (PrAeger 1921, FröDERSTRöM 1931). In Southern Europe S. tenuifolium is restricted to Spain, Portugal, S. France, S. Italy, S. Yugoslavia (Montenegro, Macedonia), Albania, Greece, and S. Bulgaria (WEBB 1964).

Polyploidy, which is a common feature in many Sedum species, also occurs in $S$. tenuifolium. Until now the chromosome numbers $2 n=24$ in plants originating from Portugal (Fernandes \& QueIRós 1971, 'T HART 1972) and 2n = 72 in plants originating from the Sierra Nevada ('T HART 1972) have been reported. In Greek plants the chromosome number $2 n=72$ has been found ('t Hart, unpubl.).

* Mededelingen van het Botanisch Museum en Herbarium van de Rijksuniversiteit te Utrecht. No. 411 . 
This paper deals with the morphological variation in $S$. tenuifolium, found to be the counterpart of the cytological variation in this species.

\section{MATERIAL}

Specimens from the following herbaria have been used; Museum of Natural History, Budapest (BP), Botanical Institute of the University of Coimbra (COI), Botanical Museum and Herbarium, Lund (LD), Komarov Botanical Institute, Leningrad (LE), Bioloski Institut, Sarajewo (SARA), Botanical Museum and Herbarium, Utrecht (U), Naturhistorisches Museum, Wien (W), Botanisches Institut und Botanischer Garten der Universität Wien (WU).

\section{RESULTS}

Within large parts of its area $S$. tenuifolium shows little or no infraspecific morphological variation. However, plants originating from France and the northern and central parts of the Iberian Peninsula differ markedly from those from the other parts of the area. The differences observed are the following: 1. The plants from France and the northern and central parts of the Iberian Peninsula have propagules without or with very short stalks. The length of the stalks varies between 0 and $4 \mathrm{~cm}$ (mean $0.5 \mathrm{~cm}$ ). In no single specimen of this group the mean length of the stalks exceeds $1.5 \mathrm{~cm}$ ( fig. I).

The plants from the other parts of the area have propagules with long stalks. The length of the stalks varies from 0 to $30 \mathrm{~cm}$ (average, depending on the region, $2.5-6 \mathrm{~cm}$ ). In every specimen from this group the mean length of the stalks is more than $1 \mathrm{~cm}$.

2. The propagules of the plants with short-stalked propagules are usually borne on the plant in a suberect position (fig. $2 A$ ). The stalks of the propagules of the plants with long-stalked propagules are usually prostrate. The propagules are in an almost horizontal position or slightly ascending ( $f i g .2 B$ ). 3. The dead leaves attached to the propagules of the plants with short-stalked propagules are always narrow, straight and appressed (fig. $2 \mathrm{~A}$ ), those of the plants with long-stalked propagules bent outward, usually broader, and of a bright white colour (fig. 2B).

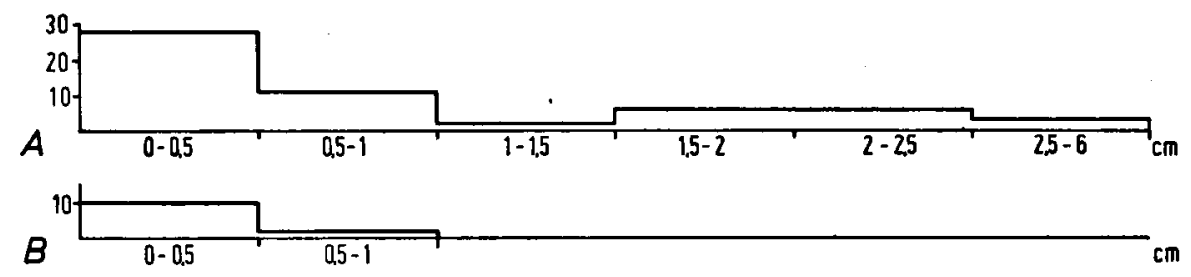

Fig. 1. Histogram of the mean length of the stalks of the propagules of 56 specimens of S. tenuifolium ssp. tenuifolium and ssp. ibericum from Portugal and Spain (A) and of 11 specimens of $S$. tenuifolium ssp. ibericum from France (B). 

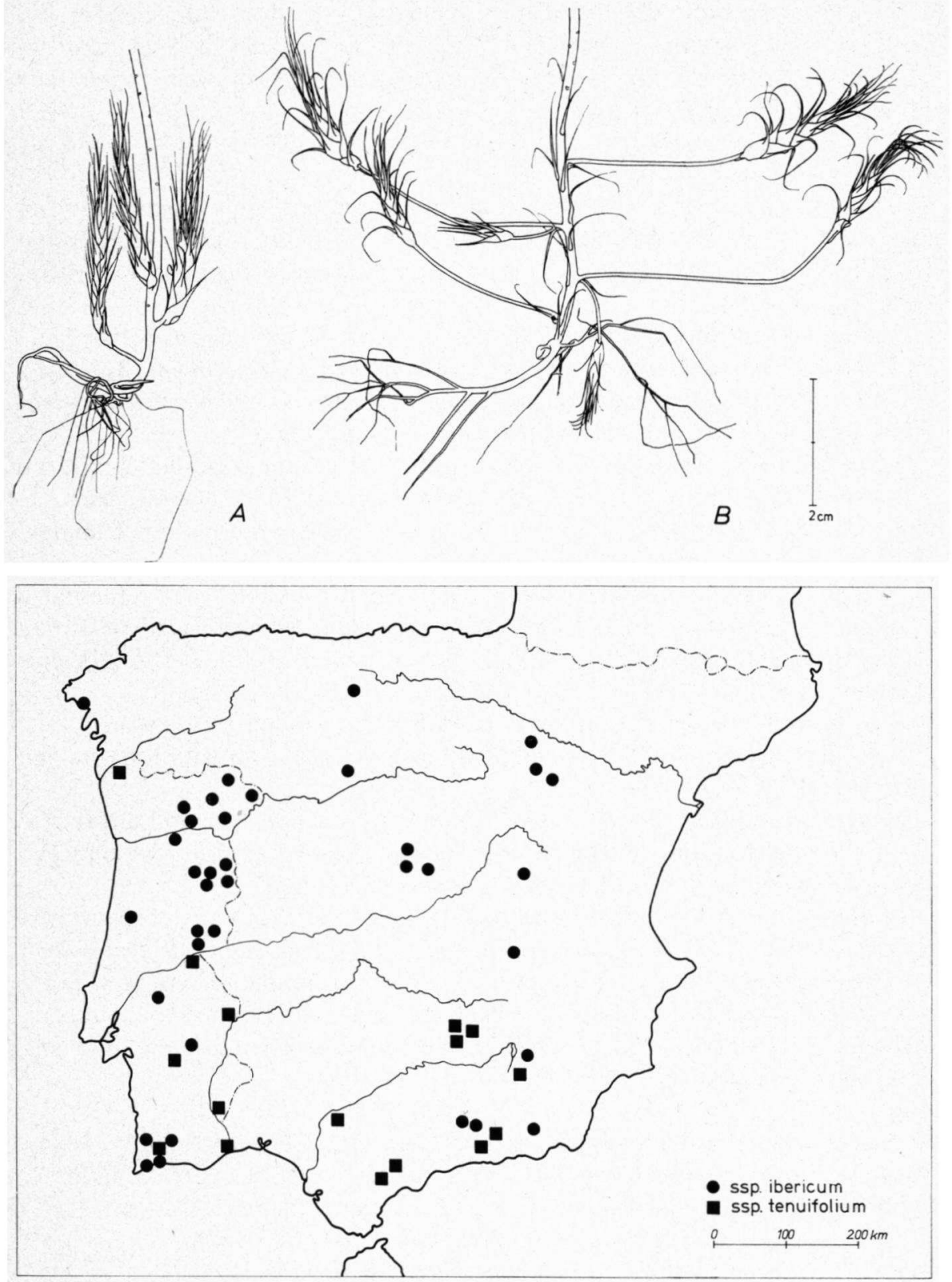

Fig. 2. Basal parts with propagules of two Portugese specimens of S. tenuifolium demonstrating the differences between the two subspecies, and a map showing the distribution of both subspecies in the Iberian Peninsula.
A. S. tenuifolium ssp. ibericum (Tras-os-Montes, vic. of Alfândega da Fe, Ochôa)
B. S. tenuifolium ssp. tenuifolium (Algarve, Vila Real de St. Antonio Graia de Monte Gordo, Fontes c.s. 1773)


Both diploid plants of $S$. tenuifolium originating from Portugal belong to the iorm with short-stalked propagules. The hexaploid plants of $S$. tenuifolium from Spain and from Greece were found to belong to the form with long-stalked propagules.

\section{DISCUSSION}

The original description of $S$. tenuifolium was based on plants originating from the vicinity of Athens (SibThorp \& SMITH 1806). A figure (SibThORP \& SMITH 1825) confirms that the type of $S$. tenuifolium belongs to the form with longstalked propagules.

According to FRöDERSTRöm (1932) S. amplexicaule DC., S. rostratum Ten., and Sempervivum anomalum Lag. are identical with $S$. tenuifolium. This view is accepted by the present author, although the type specimens were not seen. For that reason these taxa will only be discussed briefly here.

- S. amplexicaule was based on plants from the Cévennes (see DE CANDOLle 1828a). According to a figure (DE CANDOLLE 1828b) $S$. amplexicaule has short-stalked propagules, just like the specimens from southern France studied by the present author. However, these French specimens are far from typical for the form with short-stalked propagules. Most probable they represent a separate northern race of this form which is few-flowered and usually less than $12 \mathrm{~cm}$ in height. This race also occurs in N.E. Spain, in the Sierra de Vicor, Sierra de Moncayo, and Sierra de Cuenca.

- S. rostratum was based on plants from Southern Italy (see TENORE 1831). All Italian specimens of $S$. tenuifolium belong to the form with long-stalked propagules.

- Sempervivum anomalum was based on plants from Chamartin and Guadarrama (Prov. of Madrid). All specimens of $S$. tenuifolium from this region turned out to belong to the form with short-stalked propagules ( $f$ ig. 2).

In none of the descriptions of the taxa discussed the characters of the propagules and their stalks are mentioned. However, both forms of $S$. tenuifolium are easily distinguishable, and certainly deserve taxonomic recognition. Since both forms occupy distinc areas, and also have different chromosome numbers, the rank of subspecies seems to be most appropriate. Therefore the following delimitation is proposed:

Sedum tenuifolium (Sibth. \& Sm.) Strobl, Oest. Bot. Zeitschr. 34: 255. 1884. Basionym: Sempervivum tenuifolium Sibth. \& Sm. Flor. Graec. I: 335.1806. Synonyms: Sempervivum anomalum Lag. Gen. et Spec. Plant.: 17. 1816.

Sedum amplexicaule DC. Mém. Soc. Agric.: 80. 1808.

Sedum rostratum Ten. Prodr. Flor. Neap. p. 26. 1811-13.

Sedum carinatum Link ex Sprengel Syst. Veg. II ed. 16: 435.1825.

subsp. tenuifolium nom. illegit.

Propagules on stalks of $0-30(2.5-6) \mathrm{cm}$, clothed with white dead leaves bent outward. Stalks prostrate. Propagules prostrate or slightly ascending. Chromo- 
some number $2 \mathrm{n}=72$. North Africa, Southern Portugal, Southern Spain, Italy, Yugoslavia, Albania, Greece, Bulgaria, and Asia Minor.

subsp. ibericum nov. ssp.

Propagula ascendentia, sine caulibus sive caulibus brevibus. Caules propagulorum ad $0-4(0.5) \mathrm{cm}$ longi. Folia mortua propagulorum recta et adpressa. Chromosomatum numerus $2 \mathrm{n}=24$. Lusitania, Hispania borealis et centralis et Gallia meridionalis.

Type: Portugal, Tras-os-Montes Alto Douro, Fonte da Assoreira, on the road from Mirandela to Bragança, Fernandes, Matos \& Matos 5459, 24.VI.1955 (COI; isotypes LD and U).

\section{ACKNOWLEDGEMENT}

The author wishes to express his gratitude to the Directors and Curators of the herbaria who sent material on loan, and to Prof. Dr. K. U. Kramer for the correction of the text.

\section{REFERENCES}

De CANdolle, A. P. (1808): Mém. de la Soc. del'Agriculture. (not seen)

- (1828a): Prodromus systematis naturalis, III. Paris.

- (1828b): Mémoire sur la famille des Crassulacées. Paris.

FERNANDES, A. \& M. Queirós (1971): Sur la caryologie de quelques plantes récoltées pendant la IIIème réunion de botanique péninsulaire. Mem. Soc. Brot. II. 21 : 343-385.

Fröderström, H. (1932): The genus Sedum L., III. Acta Horti Gotoburg. VII, app.: 1-126.

HART, H. 'T (1972): Chromosome numbers in the series Rupestria Berger of the genus Sedum L. Acta Bot. Neerl. $21: 428-435$.

LAGASCA, M. (1816): Genera et species plantarum. Madrid.

Praeger, R. L. (1921): An account of the genus Sedum as found in cultivation. J. Roy. Hort. Soc. XLVI: $1-314$.

SiBTHORP, J. \& J. E. SMith (1806): Florae graecae prodromus, 1. London.

- \& - (1825): Flora graeca, V. London.

SPRENGEL, C. (1825): Systema vegetabilium, II. (editio XVI) Göttingen.

TENORE, M. (1811-13): Prodromus florae neapolitanae. (not seen).

- (1831): Sylloge plantarum vascularium florae neapolitanae. Napoli.

WEBB, D. A. (1964): Crassulaceae, in Flora Europaea, I. Cambridge.

\section{SPECIMENS EXAMINED (France, Portugal, and Spain)}

Sedum tenuifolium (Sibth. \& Sm.) Strobl ssp. ibericum FranCE: Cévennes, Anonymus (LE); Dep. Gard; Espèrou, Anonymus (LD, W); On rocks and sandy places near Camprieux, Anthouard (BP, LD, W); Le Vigan, Anthouard (LD); Le Vigan, Grenier (W); Dep. Lozère; Mende, Anonymus (LD); La Lozère, Brosi (LE); Mende, Leithner (W); Lozère, ProsI (W); Dep. Vaucluse; Mont Ventoux, Magnier (LD);

Portugal: Prov. Alentejo Alto; Evora, Moller (COI); Prov. Algarve; Coastal sands at Lagos, Bourgeau 1873 (BP, LD); Caldas de Monchique, Matos c.s. 1795 (COI); Monchique, Moller (COI); Portimão, Welwitsch 331 (LE); Prov. Beira Alta; Between Vilar Formoso and Castelo Boru, Fernandes c.s. 3940 (COI, LD, U); Vic. of Guarda, Fernandes c.s. 4384 (COr, LD); Celorico da Beira, Fernandes \& Sousa 3438 (COI); Vic. of Guarda, Fernandes \& Sousa 3456 (COI); Vic. of Almeida, Ferreira (COI); Prov. Beira Baixa; Banks of Rio Ponsul, on the road from Castelo Branco to Malpica, Fernandes c.s. 5879 (COI, LD, U); Between Oledo and Idanha-a-Nova, Fernandes c.s. 6004 (COI, LD, U); Vic. of Castelo Branco, Fernandes 
c.s. 8558 (COI); Prov. Beira Litoral; Vic. of Coimbra, Ferreira (COI); Prov. Ribatejo; Montargil, Cortezão (COI); Prov. Tras-os-Montes Alto Douro; Road from Lamego to Régua, ca. $5 \mathrm{~km}$ from Lamego, Fernandes c.s. 6240 (COI); Favaios, Ferreira (COI); Vic. of Miranda do Douro, Mariz (COI); Vic. of Alfândega da Fé, Ochôa (COI); Fontainhas, between Sabrosa and Pinhão, Paiva c.s. 8177 (COI); Andados, $12 \mathrm{~km}$ from Bragança to Valpaços, Paiva c.s. 10075 (COI);

SPAIN: Prov. Almeria; Rio Grande da Nacimiento, Nilsson 883 (LD); Prov. La Coruña; Between Tal and Muros, along the coast, de Smidt 39 (U); Prov. Cuenca; Serrania de Cuenca, Gandoger (W); About $7 \mathrm{~km} \mathrm{W.} \mathrm{of} \mathrm{Cañete,} \mathrm{ca.} 1000 \mathrm{~m}$, Stud. Rheno-Traj. $64-484$ (U); Between Villarrobledo and San Clemente, Stud. Rheno-Traj. 64-647 (U); Prov. Granada; On old walls at Granada, Funk (W); Granada, on rocks at the Alhambra, Funk (W); Sierra Alfacar, Winkler (LE); Prov. Jaén; Sierra de Aliaraz et Jaén, Sierra Segura in a dry meadow, 1000-1500 m, Porta \& Rigo 403 (SARA); Prov. Madrid; Sierra de Guadarrama, Bourgeau? (LE); Sierra de Guadarrama, Bourgeau 2217 (LD, W); Casa del Campo near Madrid, Leresche (LE); Prov. Palencia; Penna Redonda, W. of Cervera, Leresche (BP); Prov. Valladolid; Valladolid, Pinus forest, Sennen 62 (W); Prov. Zaragoza; Sierra de Vicor, montaneous, on rocks, Vicioso (LD); Calatayud, montaneous, on rocks, Vicioso (LD, U); In Quercus forest on the E. side of the Sierra de Moncayo, ca. $2500 \mathrm{f}$, Willkomm 407 (LE, W).

\section{Sedum tenuifolium (Sibth. \& Sm.) Strobl ssp. tenuifolium}

Portugal: Prov. Alentejo Alto; Alcacovas, Assumpção (COI); Vic. of Elvas, da Silva Senna (COI); Prov. Alentejo Baixo; Mertola, Moller 524 (COI, LD); Prov. Algarve; Vila Real de St. Antonio Graia de Monte Gordo, Fontes c.s. 1773 (W); Serra do Picota, Welwitsch 4622 (COI); Prov. Beira Baixa; Vila Velha de Rodão, bank of Rio Tejo, Fernandes c.s. 6926 (COI); Prov. Minho; Banks of Rio Minho, Valladares, da Cunha (COI);

SpaIN: Prov. Granada; Mountains near Granada, 8000-10000 f, Boissier (LE, W); Sierra Nevada, 1200-1300 m, Stud. Rheno-Traj. 62-778 (U); Prov. Jaén; Sierra de Segura at Los Choros, Bourgeau 664 (LD, LE); Near Puente del Rey S. of Desfiladero de Despeñaperros, 600 m, Greuter S7155 (LD, W); Desfiladero de Despeñaperros, Stud. Rheno-Traj. 62-1327 (U); Sierra Morena, Collado de los Jardines, N.E. of Santa Elena, Stud. Rheno-Traj. 64-854 (U); Prov. Málaga; Ronda, Willkomm 565 (W); Ronda, Winkler (BP); Prov. Sevilla; Between Carmona and Lora del Rio, Stud. Rheno-Traj. 59-122(U). 